Przegląd Prawa Konstytucyjnego

- -ISSN 2082-1212--------

DOI 10.15804/ppk.2017.01.13

$-\mathrm{Nr} 1(35) / 2017$

\title{
Recenzja
}

\section{Anna Maria Kosińska, Kulturalne prawa człowieka. Regulacje normatywne i ich realizacja, Wydawnictwo KUL, Lublin 2014, ss. 340}

Nakładem Wydawnictwa KUL ukazała się książka traktująca o zagadnieniu niezwykle rzadko poruszanym w literaturze prawniczej. Na rynku wydawniczym spotyka się co prawda pozycje dotyczące dziedzictwa kulturalnego bądź dóbr kultury, lecz są to teksty pisane z punktu widzenia prawa międzynarodowego, karnego bądź cywilnego, albo też omawiające zagadnienie bardzo wąsko, np. pod kątem funkcjonowania określonych instytucji: muzeów, bibliotek. Kulturalne prawa człowieka nie stanowią przedmiotu monografii. Zagadnienie to poruszane było jedynie w formie rozdziału w monografii wieloautorskiej, bądź komentarzy do stosownego artykułu Konstytucji RP. Te próby omówienia znaczenia prawnego praw kulturalnych stanowią najczęściej próby niewyczerpujące lub w gruncie rzeczy nieudane ${ }^{1}$. Kulturalne prawa człowieka stanowią więc pozycję wyjątkową już przez wzgląd na swój temat, szeroki zakres jego omówienia i konstytucyjną perspektywę ukazania przedmiotowych zagadnień.

1 Wyjątkiem w tym zakresie są publikacje autorstwa lub współautorstwa M. Jabłońskiego, np. Wolności z art. 73 Konstytucji RP, [w:] Prawa i wolności obywatelskie w Konstytucji RP, red. B. Banaszak, A. Preisner, Warszawa 2002; Wolność twórczości naukowej i artystycznej oraz dostępu do dóbr kultury (współautor J. Węgrzyn), [w:] Realizacja i ochrona konstytucyjnych wolności i praw jednostki w polskim porzadku prawnym, red. M. Jabłoński, Wrocław 2014. Do dobrych komentarzy art. 73 Konstytucji zaliczam np. tekst autorstwa L. Garlickiego, Rozdziat II „Wolności, prawa i obowiązi człowieka i obywatela”, artykut 73, [w:] Konstytucja Rzeczypospolitej polskiej. Komentarz,T. 3, red. L. Garlicki, Warszawa 2003, s. 4. 
Recenzowana książka składa się z czterech rozdziałów, poruszających zagadnienia związane z prawami kulturalnymi, uszeregowane zarówno w układzie chronologicznym, jak i przedmiotowym w sposób pozwalający na zgrabne poprowadzenie wywodów i udowodnienie wskazanych we wstępie tez.

Rozdział I Homo culturus - rozumienie kultury w interpretacji praw kulturalnych przybliża zjawisko kultury w szerokim kontekście. Pomimo typowo prawniczego charakteru pracy A.M. Kosińska - w celu zdefiniowania kultury - sięga do dorobku przedstawicieli różnych dziedzin nauki, m.in. socjologii, kulturoznawstwa, filozofii kultury. Prezentuje powstałe w tym zakresie teorie, typy definicji i wypracowane przez różnych autorów metody badań nad kulturą. Co istotne nie ogranicza się ona do przytoczenia suchych definicji kultury, lecz doszukuje się głębokiego ich sensu, zgłębia filozofię kultury „wyznawaną” przez twórców tychże definicji. W toku procesu badawczego dobiera myślicieli, których filozofia pozwala na postawienie kultury na należnym jej miejscu, jako istotnego zjawiska towarzyszącego człowiekowi i decydującego o jego człowieczeństwie.

Autorka przedstawia też w ciekawy sposób relacje pomiędzy kulturą a cywilizacją, w toku których dochodzi do wniosku, że zakresy definicji tych pojęć ani nie są całkowicie rozłączne, ani też się nie pokrywają. Ostatecznie zgadza się z poglądem, w myśl którego relacje między kulturą a cywilizacją opierają się na ich chronologicznym następstwie. Istotą kultury jest twórczość, wytwarzanie wartości, a cywilizacja polega na udoskonalaniu i przetwarzaniu. Rozgraniczenie kultury i cywilizacji jest więc niemożliwe, jednak jeśli cywilizacja jest oderwana od kultury, nie niesie żadnych wartości.

Ciekawe są rozważania nad kulturą globalną i masową oraz nad konsekwencjami wyróżnienia kultury masowej dla nauk prawnych. Ogólnie kultura masowa oceniona została w recenzowanej książce negatywnie, jako zjawisko dające się sklasyfikować z punktu widzenia standaryzacji i ilości, a nie wartości. Może ona jednak nieść wartości i tylko w takim zakresie objęta powinna być regulacją prawną. Kultura globalna niesie niebezpieczeństwo, ponieważ wprowadzając jednolite wzorce wypiera kulturę narodową, lokalną; procesy globalizacji trudne są do oceny i nie podlegają kontroli. W pracy tej akcentuje się natomiast takie aspekty kultury, które wynikają z natury ludzkiej oraz z faktu egzystowania człowieka w grupie społecznej. Wychodząc 
z tego założenia Autorka omawia zagadnienie tożsamości kulturowej i specyfikę kultury polskiej.

Rozdział II Prawa kulturalne - pojęcie i ochrona w systemie międzynarodowym prezentuje kolejne akty prawa międzynarodowego w rozdzieleniu na system ONZ, system UNESCO i regionalne systemy ochrony praw człowieka takie jak OBWE Rada Europy i Unia Europejska. W celu oddania należytego charakteru i miejsca praw kulturalnych w poszczególnych aktach, jak i w ramach całego systemu, Autorka wychodzi od przybliżenia podziału praw człowieka na prawa poszczególnych generacji. Po tak zarysowanym tle wyjaśnia ona czym są prawa kulturalne oraz do której z generacji praw człowieka są one zaliczane. Wszelkie akty prawne i regulowane przez nie kwestie omówione są przez pryzmat praw kulturalnych. Autorka bada przepisy, które odnoszą się do tej kwestii bezpośrednio, jak również stara się wyinterpretować $\mathrm{z}$ innych przepisów czy i w jakim stopniu mogą one być zastosowane do praw kulturalnych. Ten proces wymaga od badacza pogłębionej wiedzy na temat specyfiki zjawiska, albowiem tylko ona pozwoli na taką interpretację stosownych przepisów, która umożliwi odniesienie ich do sytuacji realizacji bądź przestrzegania praw kulturalnych.

Rozdział III Uregulowanie praw kulturalnych $w$ konstytucjach polskich XX wieku stanowi analizę systemu prawa polskiego w poszczególnych okresach historycznych. Proces ten dotyczy aktów rangi konstytucji, ustaw, i aktów innego typu (dekretów, manifestów). Pod kątem praw kulturalnych badaniom poddane zostały np. ustawy budżetowe okresu II RP. Jest to zabieg atrakcyjny, rzucający światło na sferę funkcjonowania kultury w okresie międzywojennym. W dalszej części rozdziału Autorka stara się obiektywnie ocenić podstawy prawne funkcjonowania sfery kultury w okresie PRL podkreślając jednocześnie, że sama kultura w czasach tych była „niezwykle okrojona”. Władze zweryfikowały bowiem dotychczasowy dorobek artystyczny, umniejszały rolę kultury sakralnej, eliminowały rolę, jaką dla kultury pełniły mniejszości narodowe i etniczne, itp. Tak więc o ile rozbudowany arsenał przepisów konstytucyjnych mógłby dawać podstawy do prowadzenia racjonalnej polityki kulturalnej, to działania władz czyniły je fasadowymi poprzez ograniczanie kultury do tych zjawisk i działań, które zyskiwały akceptację władz ze względów ideologicznych. 
Natomiast w odniesieniu do aktualnie obowiązującego systemu prawnego, analiza obejmuje jedynie przepisy Konstytucji RP. Jest ona wielowarstwowa w takim znaczeniu, że w zakresie przepisów art. 5, 6 i 73 przedstawiono zarówno procedury techniczne (np. jak zagadnienie praw kulturalnych uregulowane było w złożonych projektach konstytucji, prace nad aktualną konstytucją w Komisji Konstytucyjnej Zgromadzenia Narodowego, dyskusje nad redakcją poszczególnych przepisów), omówiono ich znaczenie prawne jak też sięgnięto głębiej: do aksjologii uregulowań, do moralności i etyki, które legły u podstaw poszczególnych regulacji. Co istotne Autorka bierze pod uwagę wszelkie postanowienia Konstytucji, jakie się do działalności kulturalnej odnoszą bezpośrednio i pośrednio, w efekcie czego słusznie stwierdza: „Wydawać by się mogło, że regulacja ta jest nad wyraz skromna. Jednak po analizie innych przepisów Konstytucji można zauważyć, że prawa kulturalne regulowane są w niej znacznie szerzej” (s. 173). „Uświadomienie sobie relacji i powiązań pomiędzy poszczególnymi wolnościami, pozwala zrozumieć, że pomimo pozornie wąskiej regulacji, prawa i wolności kulturalne są regulowane w Konstytucji dość szeroko i właściwe ich odczytanie stwarza duże gwarancje ochrony jednostki”. (s. 209-210)

Rozdział IV Realizacja praw kulturalnych $w$ III RP skupia się na przedstawieniu tych podmiotów w państwie, których rola polega na realizacji całości lub jedynie pewnego wycinka praw kulturalnych w Polsce. Najwięcej uwagi Autorka poświęciła ukazaniu struktury i działań, jakie na rzecz realizacji praw kulturalnych podejmuje Minister Kultury i Dziedzictwa Narodowego. Potencjał tegoż ministra wynika $z$ faktu dysponowania rozległymi kompetencjami polegającymi na sprawowaniu mecenatu nad kulturą, prowadzeniu stosownych strategii i programów, możliwości ustanawiania nagród, medali i odznaczeń, organizowaniu kongresów. Minister kultury prowadzi też szereg instytucji kultury, które wspierają jego działania i - poprzez swoje fachowe przygotowanie - przyczyniają się do sprawności funkcjonowania ministerstwa. Są wśród nich też takie, które prowadzą działalność kulturalną polegającą na promocji i upowszechnianiu kultury polskiej w kraju i za granicą. Zwrócono też uwagę, że sferą kultury zajmują się również inni ministrowie: Minister Spraw Zagranicznych, Minister Edukacji oraz Minister Nauki i Szkolnictwa Wyższego. Oprócz organów władzy centralnej, przedstawiono jaką rolę w realizacji praw kultu- 
ralnych i udostępnianiu kultury spełniają Kościoły i związki wyznaniowe, media oraz organizacje pozarządowe.

Pisząc o prawach kulturalnych, dostępie do kultury i gwarancjach prawnych (konstytucyjnych), Autorka postanowiła zbadać, jaki jest w praktyce poziom świadomości w tym zakresie studentów, którzy co prawda nie będą zawodowo zajmować się kulturą, ale z racji ukończenia studiów wyższych pretendują do miana inteligencji. Przeprowadzone przez nią badanie ankietowe wykazało niestety niski poziom świadomości studenckiej na temat przysługujących jednostce praw oraz instytucji odpowiedzialnych za propagowanie kultury i prowadzenie działalności kulturalnej. Wynika z nich również, iż w małych miejscowościach utrudniony jest dostęp do oferty kulturalnej, a środowisko studenckie ma ograniczone możliwości finansowe. Stąd wniosek o ogromnej roli państwa w tworzeniu dostępu do kultury (np. dostępu do kin), co pozwoli na ukształtowanie „społeczeństwa obywatelskiego zanurzonego w kulturze jako pochodnej godności i źródle człowieczeństwa”.

Na przełomie recenzowanej książki A.M. Kosińska udowadnia postawione we wstępie tezy, wykazuje świadomość specyfiki metod i narzędzi, którymi w tym celu należy się posłużyć; weryfikuje określone kategorie i świadomie wybiera tę perspektywę (s. 17), która, jej zdaniem, zagwarantuje właściwą interpretację przepisów konstytucyjnych poddanych analizie.

Autorka prezentuje głębokie przemyślenia o kulturze, jako o wychowaniu do człowieczeństwa, jako o zjawisku, które jest nieodzowne dla człowieczeństwa (s. 38), odróżniającym człowieka od pozostałych zwierzą. Wątki aksjologiczne są bardzo mocno zaakcentowane. Autorka przedstawia prawa kulturalne jako narzędzia ochrony człowieczeństwa i jego godności. Całość wywodów w książce oparta jest na chrześcijańskim fundamencie. Przewija się to w całej pracy, tak przy wskazywaniu kryteriów pozwalających na zweryfikowanie określonych zjawisk; zakwalifikowanie ich jako nadające się do objęcia regulacją prawną, bądź nie; jako mające wartość bądź nie. Autorka przychyla się do poglądów tych autorów, którzy widzą religię, jako czynnik decydujący o „żywotności kultur” (s. 36), zapobiegający upadkowi cywilizacji zachodniej. Kościół Katolicki przedstawiony jest jako ważny podmiot propagujący idee kulturalne (s. 39-44), pełniący istotną rolę w two- 
rzeniu kultury (s. 60), w procesie zachowania i udostępniania dóbr kultury (s. 195-196). Funkcje poszczególnych artykułów Konstytucji odczytuje ona np. w nawiązaniu do słów Jana Pawła II (tak w odniesieniu do art. 6 Konstytucji, s. 198).

W rozdziale trzecim Autorka prezentuje ciekawy pogląd, zgodnie z którym w Rozdziale II Konstytucji RP brak uregulowania prawa dostępu do dóbr kultury (s. 200). Jedyny bowiem przepis tego rozdziału, który reguluje prawa kulturalne, został sformułowany tak, że w gruncie rzeczy przewiduje wolności. Tymczasem sfera wolności powinna być wolna od jakichkolwiek działań państwa. Trudno to - zdaniem Autorki - pogodzić z faktem, że nie ma możliwości korzystania z praw kulturalnych poza życiem zbiorowym społeczeństwa. Z jednej strony wolności $\mathrm{z}$ art. 73 konstytuują prawo podmiotowe, $\mathrm{z}$ drugiej zaś zadaniem państwa jest jedynie stworzenie możliwości realizacji wolności (s. 208-209; zob. też s. 214-215, 313).

Zasadniczo należy zgodzić się z wieloma poglądami Autorki prezentowanymi w recenzowanej książce. Dotyczy to niebezpieczeństw płynących dla kultury polskiej ze strony globalizacji, umasowienia kultury i szerokiego otwarcia kanałów przesyłu informacji/danych (s. 30-38 i np. 174). Podobnie jak A.M. Kosińska uważam, że obniżenie jakości kultury jest z jednej strony efektem niesłusznej marginalizacji przez państwo działań (prawodawczych, nadzorczych) i zadań w sferze kultury, z drugiej strony skutkuje rozplenianiem się tzw. kultury niskiej jako kultury łatwiejszej w odbiorze. W tym kontekście za bardzo słuszne uważam spostrzeżenia Autorki o tym, że w telewizji publicznej, która powinna wypełniać misję publiczną ,jest miażdżąca przewaga kultury popularnej nad wysoką" (s. 296), jak i jej propozycje o konieczności nauczenia się historii przez osoby starające się o uzyskanie obywatelstwa polskiego (s. 216).

Spośród uwag o charakterze de lege ferenda dotyczących regulacji konstytucyjnej na przychylną uwagę zasługują propozycje zmiany art. 73 (s. 215), art. 32 ust. 2, art. 33 (s. 190, 216). W zakresie regulacji podkonstytucyjnych Autorka proponuje ustawę o dostępie do dóbr narodowych i jej podstawowe cele (s. 285), przepisy wprowadzające takie rozmieszczenie bibliotek gminnych, aby umożliwić realne korzystanie z bibliotek wszystkim mieszkańcom kraju (s. 288). Mam natomiast wątpliwości co do propozy- 
cji polegającej na dodaniu „do Konkordatu lub ustawy o stosunku państwa do Kościoła Katolickiego ustępu o treści <<Państwo wspiera Kościół Katolicki w zachowaniu i upowszechnianiu chrześcijańskiego dziedzictwa kultury narodowej>>” (s. 276). Podobnie też odnoszę się do propozycji dodania w art. 6 Konstytucji RP ustępu 3 o treści: „«<państwo polskie zdaje sobie sprawę z roli Kościoła Katolickiego w procesie tworzenia, zachowania i udostępniania narodowego dziedzictwa kulturowego. Tym samym zobowiązuje się wspierać struktury Kościoła w zachowaniu i udostępnianiu dóbr kultury jak najszerszej liczbie obywateli >> (s. 280). Formułując te wątpliwości zdaję sobie sprawę z udziału dziedzictwa chrześcijańskiego w dziedzictwie narodowym ${ }^{2}$, jednak mam wątpliwości, czy proponowane rozwiązania nie naruszałyby zasady równości, równouprawnienia Kościoła Katolickiego względem innych kościołów i związków wyznaniowych, czy nie naruszałby konstytucyjnej zasady bezstronności i wzajemnej niezależności państwa i kościoła (art. 25).

Jeśli chodzi o uwagi krytyczne, które powinny się znaleźć nawet w pozytywnej recenzji, to podzielić je mogę na uwagi o charakterze merytorycznym i technicznym. Wśród uwag merytorycznych usytuowałabym zarzut o zbyt powierzchownym potraktowaniu pewnych zagadnień. Autorka nie zająknęła się na temat skutków wycofania w $2003 \mathrm{r}^{3}{ }^{3}$ z przepisów prawnych definicji „dobra kultury” (s. 261 i nast.). Pisze ona co prawda, że dobro kultury to pojęcie szersze niż zabytek, wiec „zabytki stanowiąc część dóbr kultury, podlegają również ochronie konstytucyjnej”. Nie zastanawia się jednak nad ochroną tych dóbr kultury, które zabytku nie stanowią. Ponadto Autorka posługuje się zamiennie pojęciami zabytek i dobro kultury, jako elementami dziedzictwa, co jest zabiegiem nieuprawnionym (s. 266-267). Nie zwróciła też ona uwagi na niebezpieczeństwo wywozu dóbr kultury za granicę w obliczu przystąpienia Polski do strefy Schengen, podczas gdy w rzeczywistości stwarza to realne niebezpieczeństwo niekontrolowanego wywo-

2 Autorka tej recenzji jest autorem publikacji Miejsce dziedzictwa sakralnego $w$ dziedzictwie narodowym Rzeczypospolitej Polskiej, [w:] Urzeczywistnianie wolności przekonań religijnych i praw z niej wynikajacych, red. S.L. Stadniczeńko, S. Rabieja, Seria: Ekumenizm i integracja, nr 25, Opole 2012.

3 Miało to miejsce na skutek zastąpienia ustawy z 15 lutego 1962 r. o ochronie dóbr kultury (Dz.U. Nr 10, poz. 48 ze zm.) ustawą z 23 lipca 2003 r. o ochronie zabytków i opiece nad zabytkami (Dz.U. Nr 162, poz. 1568 ze zm.). 
zu dóbr kultury będących istotnymi elementami dziedzictwa narodowego, pozwalających utrzymać pamięć o historii i poczucie tożsamości członków narodu polskiego (s. 264). Autorka nie przedstawiła też „za” i „przeciw” wyroku Sądu Ochrony Konkurencji i Konsumentów dotyczącego klauzul niedozwolonych (s. 284). Tymczasem sprawa ta - istotna dla dostępu do dóbr kultury i korzystania z tychże dóbr - odbiła się głośnym echem w środowisku naukowców ${ }^{4}$ i muzealników ${ }^{5}$.

Biorąc pod uwagę konstytucyjnoprawny charakter opracowania, zbyt powierzchownie potraktowano w recenzowanej książce kwestię ujęcia art. 5 i 6 Konstytucji w formie norm programowych (s. 193). To czy przepisy są normami programowymi, czy też konstruują prawo podmiotowe ma kapitalne znaczenie dla skuteczności normy zawartej w przepisie i możliwości powoływania się nań przez osoby fizyczne. Anna M. Kosińska zdaje się nie akceptować charakteru art. 5 i 6 jedynie jako normy programowej. Osobiście też pogląd ten podzielam. Jednak, w obliczu zdecydowanych opinii środowiska konstytucyjnego w tej mierze, jej argumenty przeciwne takiemu podejściu są niewystarczające. Mianowicie podkreśla ona, że: „Regulacja praw kulturalnych w art. 73 jest niepełna”. „Z tego względu pełne prawa kulturalne mogą być zrekonstruowane na podstawie art. 5, 6 i 73". Adwersarze wywodzenia praw podmiotowych $\mathrm{z}$ norm programowych opinię tę łatwo podważą, wskazując, że jednak Rozdział II Konstytucji formułuje jakieś prawo podmiotowe w zakresie działalności kulturalnej, więc nie ma podstaw wywodzenia praw podmiotowych z przepisów Rozdziału I. Przeciwstawią konstytucyjną regulację praw kulturalnych np. wolności działalności gospodarczej, która w ogóle nie jest ujęta wśród Wolności, praw i obowiązków człowieka $i$ obywatela. Uważam więc, że nauka powinna poszukiwać argumentów za wywodzeniem praw podmiotowych z norm programowych w oparciu o regułę, dającą się zastosować do każdego przypadku, nawet takiego, w ramach którego istnieje prawo podmiotowe, które w pewnym stopniu pokrywa się swym zakresem z normą programową. W literaturze mamy

\footnotetext{
4 W. Kowalski, K. Zalasińska, Prawo do wyglądu muzealiów i ich fotografowania, „Państwo i Prawo" 2013, z. 2.

5 M. Drela, M. Trzciński, Zakaz fotografowania w regulaminie muzeum - komentarz do Wyroku Sądu Ochrony Konkurencji i Konsumentów z dnia 5 maja 2010 roku, „Ochrona Zabytków” 2009, T. 57, Nr 4 (247).
} 
koncepcję minimum praw podmiotowych odpowiadających minimum obowiązków władzy publicznej Janusza Trzcińskiego. Warto jednak poszukiwać kolejnych argumentów, na które w konkretnej sytuacji mógłby się powoływać Trybunał w swym orzecznictwie.

Czasem wywodom Autorki brak przysłowiowej kropki nad „i”. Na przykład na s. 179, gdy pisze ona o zasadzie zwierzchnictwa narodu i współodpowiedzialności tegoż za realizację i ochronę wolności i praw innych ludzi, to brak tu drugiej części wywodu, która odniosłaby to wyraźnie do wolności i praw kulturalnych i unaoczniła np. poprzez przykłady jak to mogłoby się przekładać na praktykę.

Wydaje się, że do kwestii merytorycznych zaliczyć można posługiwanie się przez A.M. Kosińską terminem „zapis” zamiast terminu „przepis” (np. s. 214, 229, 278). Zapis jest instytucją prawa spadkowego, a zgodnie $\mathrm{z}$ regułami prawoznawstwa niedopuszczalne jest używanie jednego terminu na określenie dwóch różnych instytucji. Błąd ten powielany jest nagminnie przez dziennikarzy, publicystów i - co gorsza - przez prawnicze platformy internetowe, dobremu prawnikowi jednak nie przystoi.

W książce zdarzają się też błędy i niedociągnięcia techniczne, których wyeliminowanie w dużym stopniu spoczywa na samym wydawnictwie. Podobnie też wydawnictwo wydaje się być odpowiedzialnym za podanie w spisie treści błędnych numerów stron. Rozbieżność pomiędzy stroną podaną w spisie, a stroną na której rzeczywiście rozpoczyna się odpowiedni rozdział czy podrozdział wynosi od pięciu stron na początku - do ponad dwudziestu stron na końcu książki.

Kulturalne prawa człowieka. Regulacje normatywne $i$ ich realizacja jest to pozycja, którą należy wysoko ocenić i to nie tylko ze względu na jej unikalny charakter (o czym pisałam na początku niniejszej recenzji), ale również z powodów merytorycznych. Książka ta sytuuje prawa kulturalne w epicentrum rozważań i ukazuje rozległe możliwości wyinterpretowywania $\mathrm{z}$ istniejących regulacji prawnych norm, dających się zastosować do tychże praw. Autorka np. widzi związki pomiędzy ochroną środowiska, a zachowaniem naturalnego otoczenia zabytków i innych nieruchomych dóbr kultury (s. 167). W prowadzonych wywodach zauważalne jest duże zaangażowanie emocjonalne i wiara $\mathrm{w}$ znaczenie praw kulturalnych dla należytej kondycji człowieczeństwa. Kultura i prawa kulturalne przedstawione są jako pod- 
stawowe dla zachowania godności ludzi, możliwości samorozwoju, poczucia tożsamości. Znamienne jest tu stwierdzenie Autorki, że: "Człowiek bez kultury obumiera duchowo i moralnie, co ma wpływ na rozwój i kondycję całego społeczeństwa, nie tylko w sferze kultury" (s. 291). Z pewnością jest to książka, którą warto przeczytać i wracać do niej ... aby następnym razem odkryć w niej więcej niż poprzednio.

Anna Frankiewicz-Bodynek Uniwersytet Opolski 